Acta vet. scand. $1981,22,493-500$.

From the Department of Food Hygiene, State Veterinary Medical Institute, Helsinki, Finland.

\title{
GROWTH OF SOME LACTIC ACID BACTERIA IN MILK CONTAINING SULFADIAZINE
}

\author{
By \\ Stefan Soback
}

SOBACK, STEFAN: Growth of some lactic acid bacteria in milk containing sulfadiazine. Acta vet. scand. 1981, 22, 493-500. - A method for testing the effect of sulfonamides on lactic acid bacteria was developed. Sulfadiazine was used as the inhibitory substance. In the study 3 lactic acid bacteria, Lactobacillus lactis, Lactobacillus helveticus and Streptococcus thermophilus, were used. Lactic acid production, $\mathrm{pH}$ and plate count were used as parameters when monitoring the effect of Sulfadiazine on the test organisms under anaerobic conditions in milk medium.

A depressing effects due to Sulfadiazine on each of the test microbes could be demonstrated by all of the parameters used. Measurement of the inhibition in lactic acid production using Streptococcus thermophilus as test organism should be used when rapid determination of Sulfadiazine residues in milk is preferred.

sulfadiazine; lactic acid bacteria; residues.

Sulphonamides are widely used in bovine practice to control infectious diseases. Although there is a great variation on the mammary excretion of different sulphonamide compounds (Rasmussen 1958), the ratio between ultrafiltrates milk/serum range from 0.1 to 1.0, the concentrations give rise to residues in milk. Reinbold \& Reddy (1974) found dairy starter bacteria, except Streptococcus thermophilus, resistant to 8 different sulphonamides. In the case of $S$. thermophilus they pointed out that more appropriate methods should be used.

The purpose of this study was to develop a method able to detect effects of sulphonamide (or any inhibitory substance) on lactic acid producing bacteria in conditions closely related to those of a cheese factory. This led to a continuous growth model using milk as medium. Thus the problems arising from sulphonamide inhibitors containing mediums described by Reinbold \& 
Reddy could be avoided. It was also of interest to study whether the partial loss of antibacterial activity of sulphonamides in milk (Ziv 1980) would influence the inhibition in cheese factory conditions.

\section{MATERIALS AND METHODS}

Two lactobacilli, Lactobacillus lactis ATCC 12315 and Lactobacillus helveticus ATCC 15009, and Streptococcus thermophilus ATCC 19258 were used in the studies. The strains were grown in $10 \mathrm{ml}$ test tubes of MRS-broth (Oxoid LTD., London, England) at $30^{\circ} \mathrm{C}$ for $24 \mathrm{~h}$ in an anaerobic jar (Gaskit, Oxoid LTD., London, England). After the incubation the cultures were tested by the API 50 Lactobacilli (API System S.A., La Balme Les Grottes, France) for the purity and divided into $2 \mathrm{ml}$ test tubes which were restored at $-70^{\circ} \mathrm{C}$ to be used as inoculums in the study.

In the test model the strains were cultured in commercial skimmilk. The skimmilk was tested for inhibitory substances by the modified Thermocult method (Orion Diagnostica, Helsinki, Finland) described by Soback \& Lamminsivu (1979) before it was sterilized by boiling for 20 min 3 times during 3 consecutive days. The residual fat was removed after the first boiling.

The incubation took place in an apparatus (Fig. 1) especially designed for this purpose. The waterbath was equipped with a thermostat (Thermo-Boy Type B 1, MGW Lauda, Federal Republic of Germany). Two anaerobic jars $(6.5 \mathrm{l}$ ) each containing a 1.5 l Erlenmeyer flask were put in the waterbath. Magnetic stirs (Heidolph MR-80, Federal Republic of Germany) were placed under the waterbath and the magnetic bars in the flasks. Palladium coated aluminium oxide catalysts (Baltimore Biological Laboratories, Maryland, U.S.A.) were used.

Each experiment began by heating $1.0 \mathrm{l}$ of milk in each of the flasks to boiling point in order to remove oxygen from the milk. Before the flasks were placed in the anaerobic jars $4 \mathrm{ml}$ Resazurin (British Drug House LTD. No. 20101, Poole, England) solution containing $1.0 \mathrm{mg}$ Resazurin were added as redox potential indicator and $1.0 \mathrm{ml}$ of Sulfadiazine $1 \mu \mathrm{g} / \mathrm{ml}$ solution was added to one of the flasks hereafter called the test flask. Before closing, two gas producing Gaskit envelopes (Oxoid LTD., London, England) were put in each jar to produce anaerobiosis. The temperature in the waterbath was adjusted to $50^{\circ} \mathrm{C}$ which re- 


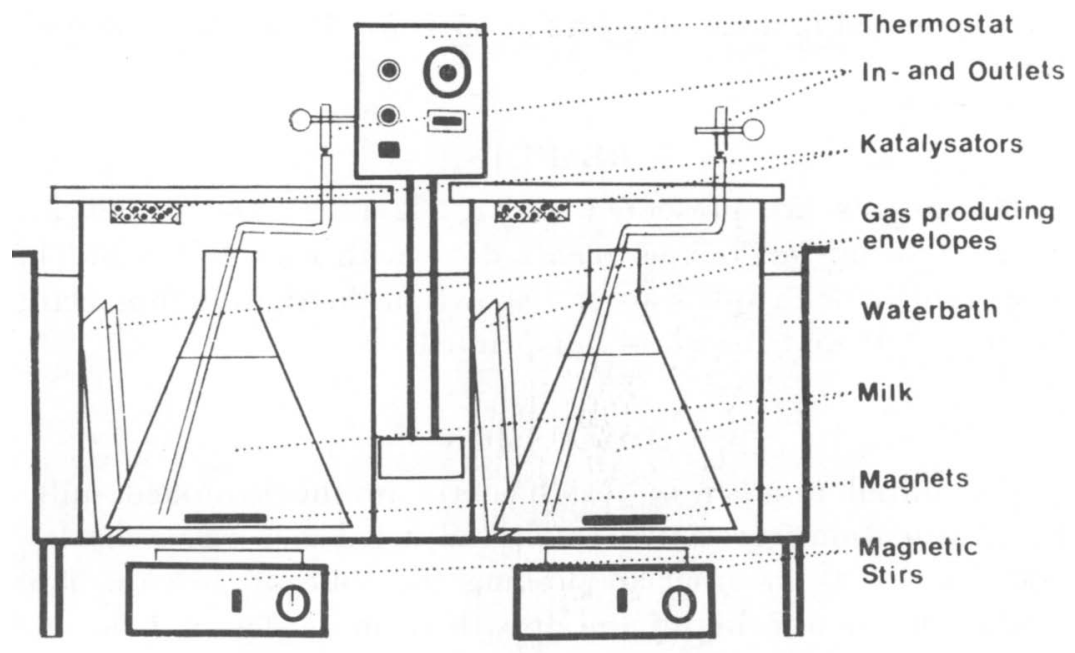

Figure 1. The incubation apparatus.

sulted in a temperature of $46^{\circ} \mathrm{C}$ in the milk. The rotation speed of the magnetic stirs were adjusted to 275 r.p.m. After $18-20 \mathrm{~h}$ from the onset of each experiment a sample of $10 \mathrm{ml}$ was taken from both flasks. From this sample an aliquot was taken to check the sterility of the milk before the inoculation. This was done by culturing the samples on blood agar aerobically and anaerobically and on Rogosa agar (Oxoid LTD., London, England) or Lee's agar (Lee et al. 1974) anaerobically. The initial pH and lactic acid levels were measured from the same samples. For pH determinations an IM-555 pH \& $\mathrm{mV}$ meter (Datex LTD., Helsinki, Finland) was used. The $\mathrm{pH}$ was always determined immediately after sampling. Lactic acid concentrations were measured according to Pryce (1969) using a Beckman-DB spectrophotometer (Fullerton, Ca., U.S.A.). Before each experiment an aliquot of the inoculum was taken for plate count determination and $0.1 \mathrm{ml}$ was mixed with $9.9 \mathrm{ml}$ of sterile milk and pipetted in each flask through an inlet pipe. The inoculation was done only if the milk in the flasks was free of the pink colour of Resazurin indicating that no leakage of oxygen had taken place. Samples of $10 \mathrm{ml}$ were taken from both flasks $0,1,3,5$, $7,9,11$ and $24 \mathrm{~h}$ after the inoculation. Each sample was investigated for plate count, $\mathrm{pH}$ and lactic acid concentration. Plate counts for lactobacilli were done from Rogosa pour plates and for S. thermophilus from spread plates on Lee's agar. The plates 
were incubated in anaerobic jars at $35^{\circ} \mathrm{C}$ for 48 and $24 \mathrm{~h}$, respectively.

\section{RESULTS}

The results are presented in Figs. 2 to 4 . The values are means \pm s.e.m. for 3 experiments done with each bacteria. The s.e.m. values for the $\mathrm{pH}$ 's are not shown in the figures thus being less than 0.01 and therefore not printed.

\section{DISCUSSION}

The initial number of test bacteria in the skimmed milks after inoculation were intentionally adjusted to a relatively low level $\left(10^{3}-10^{4}\right)$ in order to prolong the time of growth. This enabled the monitoring of the growth in more detail. The temperature was chosen to be close to $50^{\circ} \mathrm{C}$ thus resembling the temperature present in the beginning of the pressing process in Emmental cheese making (Gehriger et al. 1975). The concentration of Sulfadiazine was adjusted to $1 \mu \mathrm{g} / \mathrm{ml}$ because it is the lowest detection level of the Thermocult method for this compound.
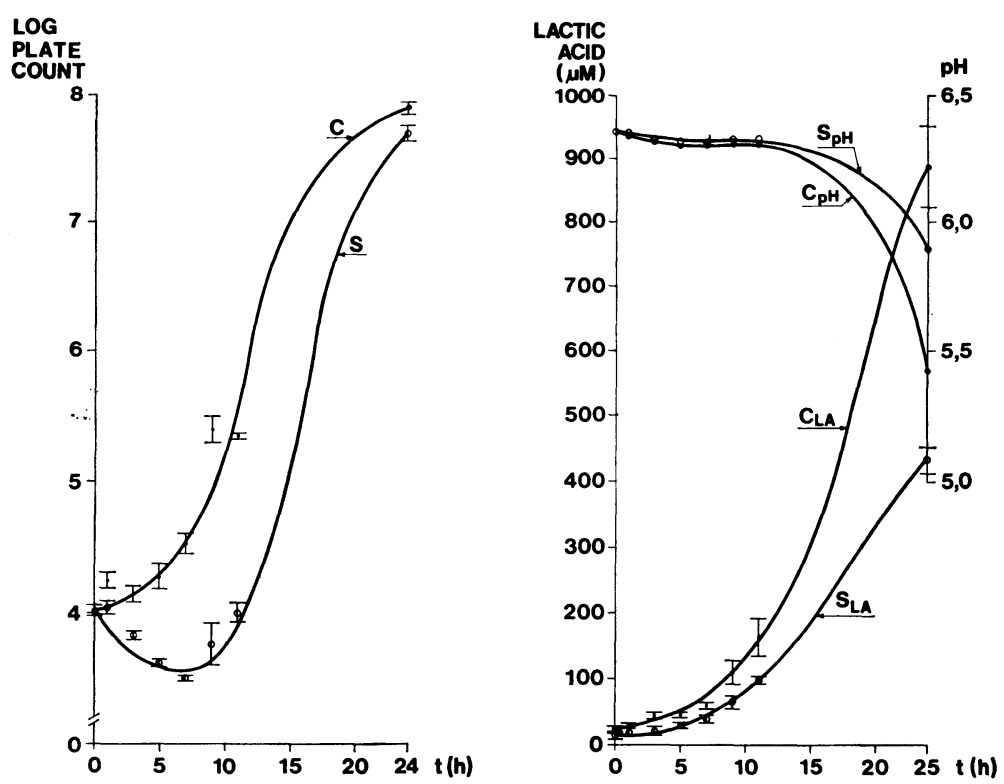

Figure 2. The plate count, $\mathrm{pH}$ and lactic acid concentration of Lactobacillus lactis $(\mathrm{C}=$ control and $\mathrm{S}=$ test $)$. 

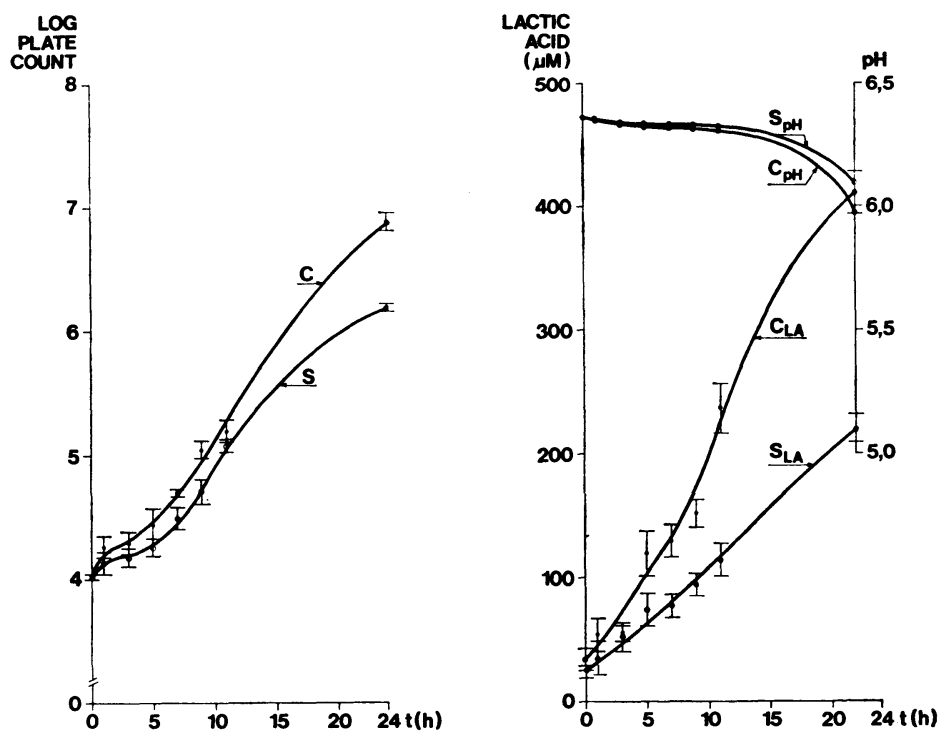

Figure 3. The plate count, $\mathrm{pH}$ and lactic acid concentration of Lactobacillus helveticus $(C=$ control and $S=$ test $)$.
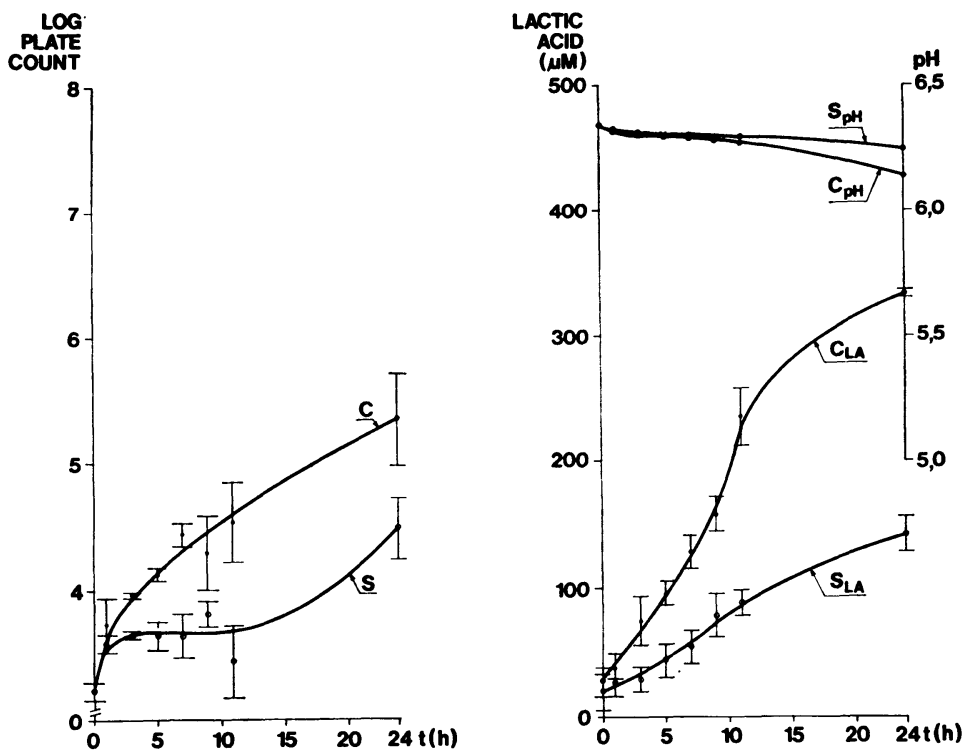

Figure 4. The plate count, $\mathrm{pH}$ and lactic acid concentration of Streptococcus thermophilus $(C=$ control and $S=$ test $)$. 
According to the results Sulfadiazine was found to inhibit the growth of all the bacteria studied but to a different degree with reference to time. In the case of L. lactis (Fig. 2) there is a clear decrease in the growth in the test flask during the first $7 \mathrm{~h}$ of incubation. S. thermophilus reaches a plateau of growth in the test flask after $1 \mathrm{~h}$ which remains stable during the next $10 \mathrm{~h}$ (Fig. 4). The growth rate of L. helveticus is least affected by Sulfadiazine during the first $11 \mathrm{~h}$ after incubation. The growth rate is practically the same as in the control medium but on a lower level (Fig. 3). After $24 \mathrm{~h}$ from inoculation the difference between the plate counts determined from samples taken from the control flask and the test flask is smallest in the case of L. lactis. The difference in plate counts is largest for S. thermophilus but only for L. helveticus the difference seems to be growing at this stadium. The growth kinetics in the control flasks are in agreement with earlier studies reviewed by Mocquot (1979).

For each of the tested bacteria the effect on the $\mathrm{pH}$ decrease due to Sulfadiazine was hardly detectable durnig the first $11 \mathrm{~h}$ of incubation (Figs. 2 to 4 ).

The difference in the mean $\mathrm{pH}$ 's after $24 \mathrm{~h}$ of incubation was only 0.1 for L. helveticus or S. thermophilus (Figs. 3 and 4). Correspondingly the difference of the mean $\mathrm{pH}$ 's for $\mathrm{L}$. lactis was found to be 0.5 . The Sulfadiazine thus markedly affects the measured $\mathrm{pH}$ lowering ability of L. lactis at $24 \mathrm{~h}$ in the milk as shown in Fig. 2. The difference in the plate count at the same time was only about $\log 0.2 / \mathrm{ml}$.

The inhibition of lactic acid production due to Sulfadiazine is consistent throughout the experiment for each bacteria studied (Figs. 2 to 4 ). The rate of the inhibition is longer for L. helveticus and S. thermophilus compared to that for L. lactis during the $11 \mathrm{~h}$ from incubation. This appears slightly controversial when the results are compared to the inhibition rates for the plate counts for the respective bacteria. At $24 \mathrm{~h}$ after inoculation the production of lactic acid was reduced to half due to Sulfadiazine inhibition for each bacteria studied. At this stage the inhibition in lactic acid production for L. lactis seems to be poorly correlated to the difference in plate count at this time.

All the parameters measured in the test model were able to detect the inhibitory effect due to Sulfadiazine on the bacteria used in this study. The effect of the decrease of $\mathrm{pH}$ was difficult 
to read during $11 \mathrm{~h}$ after inoculation obviously due to the buffering capacity of milk. Measurement of inhibition in lactic acid production seems to be a better indicator than plate count for Sulfadiazine effect due to its consistent behaviour.

\section{CONCLUSION}

Changes in each of the 3 parameters, growth rate, decrease of the $\mathrm{pH}$ and production of lactic acid, used in this study indicated a depressing effect due to Sulfadiazine on the test microbes, Lactobacillus lactis, Lactobacillus helveticus and Streptococcus thermophilus, in skimmed milk medium.

The measurement of the inhibition in lactic acid production seems to be best suited for testing milk for Sulfadiazine residues.

Streptococcus thermophilus should be preferred as test organism because of its fast and continuing response to Sulfadiazine inhibition in lactic acid production and growth.

\section{REFERENCES}

Gehriger, G., A. Wüthrich, H. Kaufmann \& J. M. Hofmann: Über die Temperaturverhältnisse im jungen Emmentalerkäse und ihre Auswirkungen. (On the temperature relations in young $\mathrm{Em}$ mental cheese and their effects). Dtsch. Molkerei-Zeit. 1975, 96, 1527-1537.

Lee, S. Y., E. R. Vedamuthu, C. J. Washam \& G. W. Reinbold: An agar medium for the differential enumeration of Yogurt starter bacteria. J. Milk Food Technol. 1974, 37, 272-276.

Mocquot, G.: Reveiws of the progress of dairy science: Swiss-type cheese. J. Dairy Res. 1979, 46, 133-160.

Pryce, J. D.: A modification of the Barker-Summerson method for determination of lactic acid. Analyst 1969, 94, 1151-1152.

Reinbold, G. W. \& M. S. Reddy: Sensitivity or resistance of dairy starter and associated microorganisms to selected antibiotics. J. Milk Food Technol. 1974, 10, 517-521.

Soback, S. \& U. Lamminsivu: The effect of proteinbinding on the excretion of three sulphonamide preparations in the milk of dairy cows, examined by chemical and microbiological methods. Nord. Vet.-Med. 1979, 31, 309-315.

Ziv, G.: Drug selection and use in mastitis: Systemic vs local therapy. J. Amer. vet. med. Ass. 1980, 176, 1109-1115. 


\section{SAMMANFATTNING}

Växt av några mjölksyrabakterier $i$ mjölk med Sulfadiatsinhalt.

En metod för testning av sulfonamiders effekt på mjölksyrabakterier utveklades. Sulfadiatsin användes som inhiberande substans. I undersökningen användes tre mjölksyrabakterier, Lactobacillus lactis, Lactobacillus helveticus och Streptococcus thermophilus. Mjölksyraproduktion, $\mathrm{pH}$ och plate count användes som parametrar, när Sulfadiatsins effekt på testorganismer undersöktes under anaerobiska förhållanden i mjölk medium.

Sulfadiatsin förorsakade en nedsättande effekt på varje testmikrob, vilket kunde påvisas med alla använda parametrar. Mätning av inhibition i mjölksyraproduktion med Streptococcus thermophilus borde användas, när snabb undersökning av Sulfadiatsin restkoncentrationer i mjölk förutsättes.

(Received September 14, 1981).

Reprints may be requested from: Stefan Soback, Orion-yhtymä Oy, Orion Pharmaceutical Co. Research Laboratories P.O.B. 19, Helsinki, Finland. 